\title{
MODEL TRANSPORTASI PENGIRIMAN PRODUK PERISHABLE DENGAN MULTI KENDARAAN
}

\author{
TRANSPORTATION MODEL FOR SHIPPING PERISHABLE PRODUCT \\ WITH MULTI MODA \\ Winanda Kartika ${ }^{1}$ \\ 1) Politeknik APP Jakarta, Jl Timbul 34, Jakarta Selatan, 12630, Indonesia \\ *)Penulis korespondensi : winanda.kartika@gmail.com \\ DOI Number : 10.30988/jmil.v3i1.72 \\ Diterima : 15032019 \\ Disetujui: 23042019 \\ Dipublikasi: 10052019 \\ Abstract \\ According to Graf theory, the shortest path determination is a problem of looking for a path between \\ two vertices in a weighted graph to obtain the minimum amount of weight.The determination of the \\ shortest path problem also called optimization problem. Several algorithms have been developed in \\ solving this problem. Each algorithm has a different way of solving a particular problem. In this \\ study, the development of algorithms was carried out to determine the critical path from one origin \\ point to one destination point on a network for the delivery of perishable products that limited time \\ window to minimize the total cost and the selection of vehicles that will be used for solving the \\ problem.The Algorithm that developed is Dijkstra algorithm. The first stages of the algorithm \\ development is to modify the network of the studied problem by making the network replication. The \\ second stage is to make problem-solving steps to minimize the total cost, consists of a fixed cost, \\ variable cost, vehicle turnover costs, deterioration cost and parking fees with modified Dijkstra \\ algorithm because the problems can not be modeled mathematically.To test the developed algorithm, \\ we used numerical examples with hypothetical data
}

Keywords: perishable product; deterioration; time window; modified Dijkstra algorithm

\section{Abstrak}

Menurut teori Graf, penentuan rute terpendek merupakan suatu persoalan mencari lintasan antara dua buah simpul pada graf berbobot untuk mendapatkan jumlah bobot yang paling minimum. Permasalahan penentuan rute terpendek disebut juga masalah optimasi.Beberapa algoritma telah dikembangkan dalam pemecahan masalah ini. Setiap algoritma memiliki cara yang berbeda dalam menyelesaikan suatu permasalahan tertentu. Pada penelitian ini, dilakukan pengembangan algoritma untuk menentukan lintasan kritis dari satu titik asal ke satu titik tujuan pada suatu jaringan untuk pengiriman produk perishable dan dibatasi jendela waktu dengan meminimumkan total biaya sekaligus pemilihan jenis kendaraan yang akan digunakan untuk pemecahan masalah. Algoritma yang dikembangkan adalah Algoritma Dijkstra. Tahapan awal pengembangan algoritma adalah memodifikasi jaringan dari masalah yang diteliti dengan cara membuat replikasi jaringan. Tahapan kedua adalah membuat langkah pemecahan masalah untuk meminimumkan total biaya yaitu biaya tetap, biaya variabel, biaya pergantian kendaraan, biaya deteriorasi dan biaya tunggu dengan modifikasi Algoritma Dijkstra. Modifikasi Dijkstra dilakukan karena permasalahan yang diteliti tidak bisa dimodelkan secara matematis. Pengujian algoritma menggunakan contoh numerik dengan data hipotetik.

Kata kunci: produk perishable; deteriorasi; jendela waktu; modifikasi Algoritma Dijkstra. 


\section{PENDAHULUAN}

Perishable adalah produk yang mengalami penurunan kualitas sepanjang umur produk [1]. Dalam pengiriman produk perishable dari titik asal ke titik tujuan, waktu sangat berperan penting karena keterlambatan kedatangan produk menyebabkan nilai ekonomis produk tersebut berkurang bahkan hilang [2]. Oleh karena itu, dibutuhkan strategi pengangkutan yang mampu mempertahankan umur simpan, sekaligus kualitas produk. Suatu model transportasi harus mampu menyusun -strategi rute kendaraan dengan total biaya yang minimum. Permasalahan ini termasuk permasalahan lintasan terpendek atau shortest path problem $(S P P)$. SPP termasuk permasalahan optimasi jaringan yang paling dasar.

Masalah lintasan terpendek merupakan masalah klasik. Namun, belum banyak penelitian yang membahas penentuan rute untuk pengiriman produk perishable tanpa penanganan khusus seperti penggunaan kendaraan cold storage. Dalam mengirimkan produk perishable, rute kendaraan menjadi faktor kritis karena apabila tidak ada strategi penentuan rute kendaraan yang optimal, produk dapat kehilangan kualitas atau penurunan nilai ekonomi [2] dan [3]. Di samping mempertahankan kualitas produk, total biaya kendaraan juga harus diminimumkan. Salah satu strategi pengiriman produk tanpa menggunakan cold storage adalah mempertimbangkan pergantian kendaraan sehingga waktu tempuh lebih singkat. Strategi tersebut menjadi tujuan dari penelitian ini.

Gambaran umum dari permasalahan yang diteliti adalah penentuan rute terpendek $(S P P)$ untuk mengangkut produk perishable dari satu titik asal ke satu titik tujuan dengan pergantian kendaraan yaitu moda darat dan udara untuk meminimumkan total biaya kendaraan. Total biaya kendaraan yaitu biaya tetap, biaya variabel, biaya pergantian kendaraan, dan biaya deteriorasi produk.
Pergantian kendaraan dilakukan pada suatu titik antara yaitu titik selain titik asal dan titik tujuan. Pergantian kendaraan dan rute memberikan total biaya kendaraan yang berbeda [4]. Dengan menggunakan kendaraan dengan waktu tempuh singkat maka biaya yang dikeluarkan besar, tetapi biaya deteriorasi produk kecil. Sebaliknya dengan menggunakan kendaraan dengan waktu tempuh lama maka biaya yang dikeluarkan kecil, tetapi biaya deteriorasi besar [5].

Kondisi nyata yang dapat menggambarkan permasalahan adalah pengangkutan ikan laut dari suatu tempat produsen ikan ke konsumen (pasar). Ikan laut merupakan produk yang mudah rusak, artinya tingkat kesegaran ikan menentukan nilai ikan tersebut. Berdasarkan penelitian yang dilakukan oleh Sartika [6], penurunan kualitas ikan secara empiris dari waktu ke waktu berbentuk grafik eksponensial yang didekati dengan persamaan, kualitas $(t)=$ kualitas awal $e^{-t / T}$, dimana $t$ adalah waktu aktivitas dan $T$ adalah waktu busuk ikan. Penurunan kualitas dianalogikan dengan kerusakan yang disebabkan oleh mikroorganisme. Untuk menjaga kualitas ikan supaya mendekati kualitas awal maka dibutuhkan suatu strategi, salah satunya mempercepat waktu aktivitas yaitu mengganti moda transportasi dengan kecepatan lebih baik. Misal pengangkutan ikan laut dari Surabaya ke Jakarta. Dari Surabaya, ikan dapat diangkut menggunakan truk dengan jalur Surabaya-Semarang-Jakarta atau Surabaya-Cirebon-Jakarta. Pada saat tiba di Semarang atau Cirebon, kendaraan dapat diganti untuk mempercepat waktu aktivitas. Apabila ikan dari Surabaya diangkut menggunakan pesawat ke Jakarta tentu biaya yang dikeluarkan besar, sedangkan jika diangkut menggunakan truk dari Surabaya-Jakarta tentunya sampai di Jakarta kualitas ikan turun bahkan busuk meskipun biaya yang dikeluarkan lebih murah. Strategi pergantian kendaraan dapat meminimalkan biaya dan tetap menjaga 
kualitas produk. Faktor lain yang dipertimbangkan adalah jendela waktu. Merujuk pada contoh permasalahan sebelumnya, dari setiap kota dilalui, tentunya ada waktu buka tutup pelayanan seperti mengganti truk dengan pesawat dimana harus mengikuti jadwal penerbangan. Penentuan lintasan terpendek dengan pembatas jendela waktu mengacu pada model yang diusulkan oleh Chen [7] dan Moungla [8].

Penelitian yang berkaitan dengan produk perishable umumnya mempertimbangkan penggunaan kendaraan cold storage untuk mempertahankan kualitas produk. Belum banyak penelitian yang membahas tentang pengiriman produk perishable dengan mempertimbangkan pergantian jenis kendaraan atau tanpa menggunakan kendaraan cold storage. Penelitian yang dilakukan oleh Chen, dkk [1], mengusulkan pengiriman produk perishable dengan kebijakan shipment consolidation. Kebijakan ini berdasarkan kualitas dan kuantitas atau quality and quantity ( $Q Q$ based policy). Konsolidasi pengiriman dilakukan ketika kuantitas produk yang akan dikirim sudah mencapai target pengiriman atau kualitas produk perishable sudah mencapai level kualitas pengiriman yang sudah ditentukan sebelumnya. Penelitian yang dilakukan oleh Chen bertujuan untuk meminimumkan biaya transportasi dengan menentukan level kualitas optimal pengiriman dan jumlah pengiriman optimal produk perishable dalam mengkonsolidasi pengiriman. Namun, penelitian yang dilakukan oleh Chen tidak mempertimbangkan lintasan kendaraan untuk pengiriman produk dari titik asal ke titik tujuan.

Oleh karena itu, penelitian yang akan dilakukan adalah menentukan lintasan kendaraan dari satu titik asal ke satu titik tujuan pada suatu jaringan untuk pengiriman produk perishable dengan multi moda untuk meminimumkan total biaya transportasi.

\section{METODE PENELITIAN}

Permasalahan yang akan dibahas adalah penentuan lintasan rute terpendek untuk pengiriman produk perishable yang mengalami deteriorasi sepanjang perjalanan dari satu titik asal ke satu titik tujuan dengan pembatas jendela waktu yang dapat meminimumkan total biaya kendaraan. Total biaya kendaraan terdiri dari biaya tetap, biaya variabel, biaya pergantian kendaraan, dan biaya deteriorasi termasuk di dalamnya biaya tunggu. Dalam penelitian ini, kendaraan yang digunakan tidak menggunakan penyimpanan khusus seperti cold storage. Oleh karena itu, pergantian kendaraan menjadi strategi mempertahankan kualitas produk dengan total biaya yang minimum. Pendekatan penelitian yang digunakan adalah pendekatan secara analitik dengan menggunakan algoritma sebagai metode pemecahan masalah.

Model yang dikembangkan menggunakan model penentuan lintasan terpendek (shortest path problem (SPP)). Penentuan lintasan terpendek merupakan masalah optimasi penentuan lintasan kendaraan terpendek dengan total biaya minimum [9]. Model acuan yang digunakan adalah model yang diusulkan oleh Weihong, dkk [10]. Tujuan akhir model transportasi pengiriman produk perishable dengan multi moda adalah menentukan lintasan kendaraan dari satu titik asal ke satu titik tujuan pada suatu jaringan untuk pengiriman produk perishabe dengan pergantian kendaraan yang digunakan untuk meminimumkan total biaya kendaraan.

Adapun ruang lingkup yang digunakan adalah:

- Sistem yang dikaji terkait dengan masalah $S P P$.

- Jenis kendaraan yang digunakan untuk pengangkutan produk perishable adalah kendaraan yang tidak mempunyai penyimpanan khusus seperti cold storage. 
- Metoda pemecahan masalah yang digunakan adalah Algoritma Dijkstra.

- Penentuan kendaraan tidak mempertimbangkan kapasitas kendaraan dan jumlah kendaraan.

- Pergantian kendaraan yang diizinkan adalah truk dengan pesawat cargo dan sebaliknya.

- Pengujian model menggunakan data hipotetik.

Tahap ini dilakukan pengembangan metode pemecahan masalah dengan melakukan modifikasi Algoritma Dijkstra. Selanjutnya model diverifikasi untuk menjamin bahwa algoritma model yang dirumuskan benar secara perhitungan dan konsisten secara logika. Verifikasi model menggunakan perhitungan numerik secara manual dan software LINGO. Setelah model terverifikasi, maka dilakukan ujicoba algoritma solusi. Ujicoba algoritma solusi menggunakan data hipotetik. Dari hasil ujicoba model dilakukan analisis terhadap solusi yang dihasilkan.

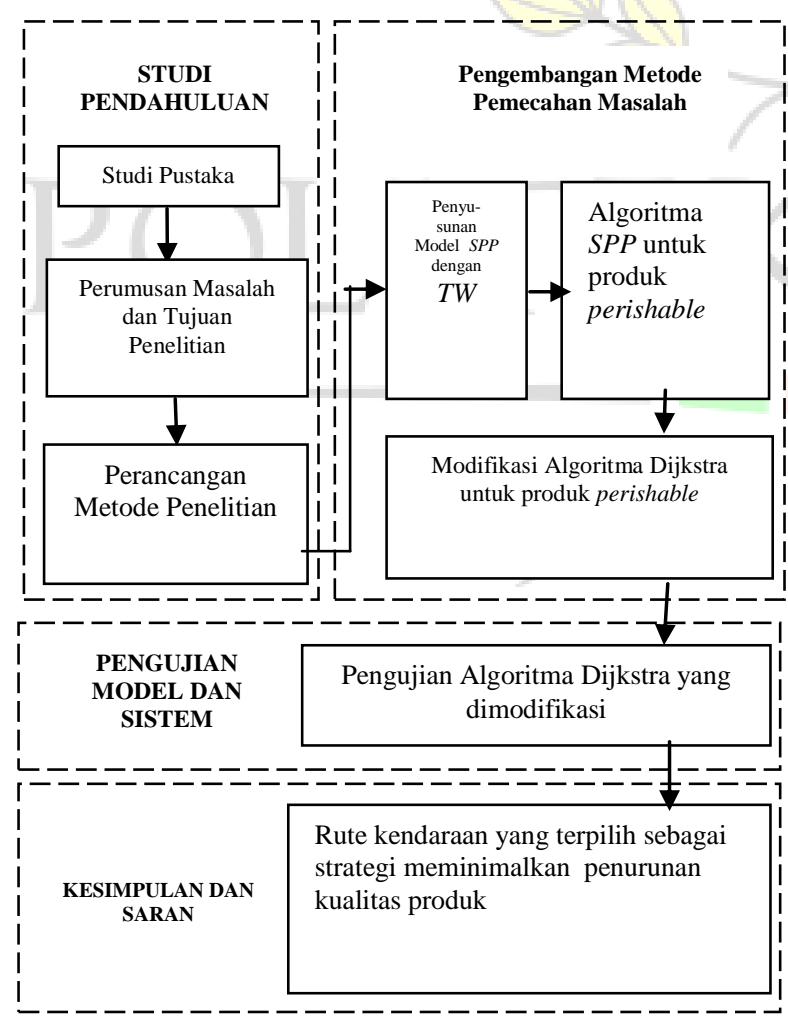

Gambar 1. Tahapan Penelitian
Penelitian menggunakan pendekatan analitik dengan algoritma sebagai metode pemecahan masalah.

\section{HASIL DAN PEMBAHASAN}

\subsection{Deskripsi Sistem}

Pengiriman produk perishable dari satu titik asal ke satu titik tujuan dengan menggunakan kendaraan. Dari titik asal terdapat dua alternatif penggunaan jenis kendaraan untuk mengangkut produk tersebut yaitu menggunakan truk atau pesawat cargo. Pemilihan dua jenis kendaraan ini berdasarkan perbedaan yang signifikan terhadap kecepatan kendaraan atau waktu tempuh tempuh yang dapat dicapai oleh kendaraan. Pada suatu titik antara $i \in$ $N /\{o, d\}$, diperbolehkan pergantian jenis kendaraan untuk menghindari penurunan kualitas produk melebihi batas toleransi ketahanan produk sebagai suatu strategi untuk mempertahankan kualitas produk dan rute kendaraan dengan total biaya yang minimum. Batas toleransi ketahanan produk adalah produk masih memiliki nilai ekonomis pada saat tiba di titik tujuan tanpa mengurangi kualitas maupun kuantitas produk. Pergantian kendaraan menyebabkan trade-off antara biaya penggunaan kendaraan dengan biaya deteriorasi produk. Biaya deteriorasi merupakan suatu fungsi terhadap waktu yang dinotasikan dengan $V(t)$ akibat penurunan kualitas produk sepanjang perjalanan. Setiap simpul ada pembatas time window yang harus dipenuhi oleh kendaraan. Kendaraan yang datang lebih awal dari time window tetap dikatakan layak melewati lintasan tersebut, tetapi akan dikenakan biaya tunggu. Namun, jika kendaraan datang melebihi batas time window maka lintasan yang dilewati kendaraan tersebut dikatakan tidak layak sehingga tidak dipertimbangkan menjadi rute kendaraan yang terpilih. Karena adanya waktu tunggu maka waktu yang masuk dalam perhitungan ada dua yaitu waktu tempuh kendaraan dan waktu perjalanan kendaraan. Waktu tempuh 
kendaraan merupakan waktu yang dibutuhkan kendaraan untuk melewati busur $i, j$, sedangkan waktu perjalanan kendaraan merupakan waktu yang dibutuhkan kendaraan untuk menempuh perjalanan dari titik asal $o$ ke titik $i$ termasuk waktu tunggu. Waktu tempuh kendaraan mempengaruhi biaya variabel kendaraan dan waktu perjalanan kendaraan mempengaruhi biaya deteriorasi.

\subsection{Struktur Jaringan Model}

Dalam struktur jaringan model $S P P$, rute kendaraan digambarkan dalam bentuk graf terdiri dari empat elemen utama yaitu simpul, busur, bobot, dan jenis kendaraan yang digunakan seperti Tabel 1.

Tabel 1. Elemen Struktur Jaringan Model

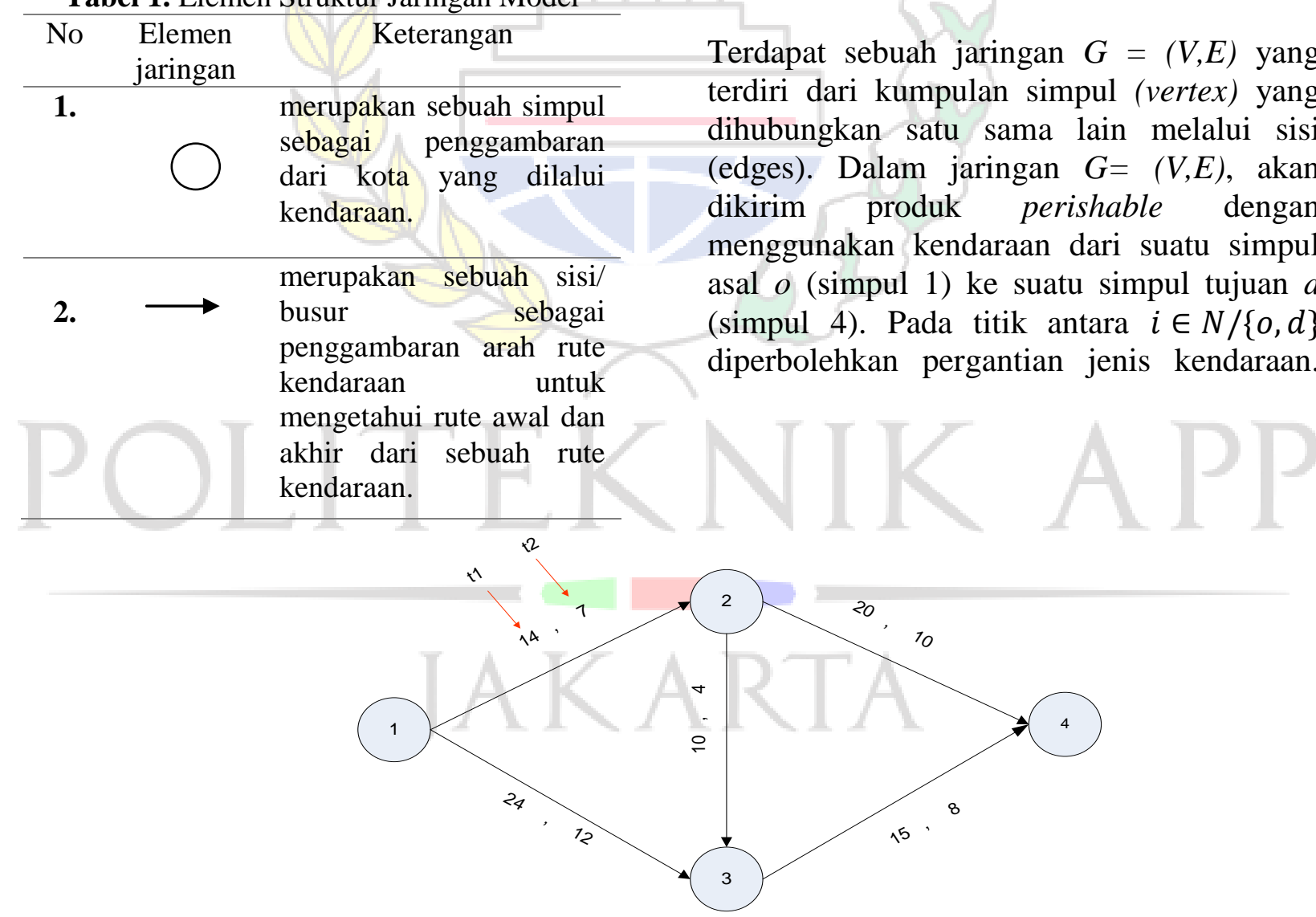

\begin{tabular}{|c|c|c|}
\hline No & $\begin{array}{l}\text { Elemen } \\
\text { jaringan }\end{array}$ & Keterangan \\
\hline 3. & 4 & $\begin{array}{l}\text { merupakan waktu yang } \\
\text { ditempuh kendaraan } \\
\text { sebagai penggambaran } \\
\text { bobot dari graf sehingaa } \\
\text { dapat diketahui berapa } \\
\text { jam waktu tempuh dari } \\
\text { kota asal ke kota tujuan. }\end{array}$ \\
\hline
\end{tabular}

4. Jenis kendaraan yang kendaraan digunakan untuk

memindahkan komoditas dari kota asal ke kota tujuan.
Ilustrasi struktur jaringan model beserta elemennya dalam bentuk graf dapat dilihat pada Gambar 2.

Terdapat sebuah jaringan $G=(V, E)$ yang terdiri dari kumpulan simpul (vertex) yang dihubungkan satu sama lain melalui sisi (edges). Dalam jaringan $G=(V, E)$, akan dikirim produk perishable dengan menggunakan kendaraan dari suatu simpul asal $o$ (simpul 1) ke suatu simpul tujuan $d$ (simpul 4). Pada titik antara $i \in N /\{o, d\}$ diperbolehkan pergantian jenis kendaraan.

Keterangan:

t1: waktu tempuh untuk kendaraan 1

t2: waktu tempuh untuk kendaraan 2

Gambar 2. Struktur jaringan model dan elemennya 


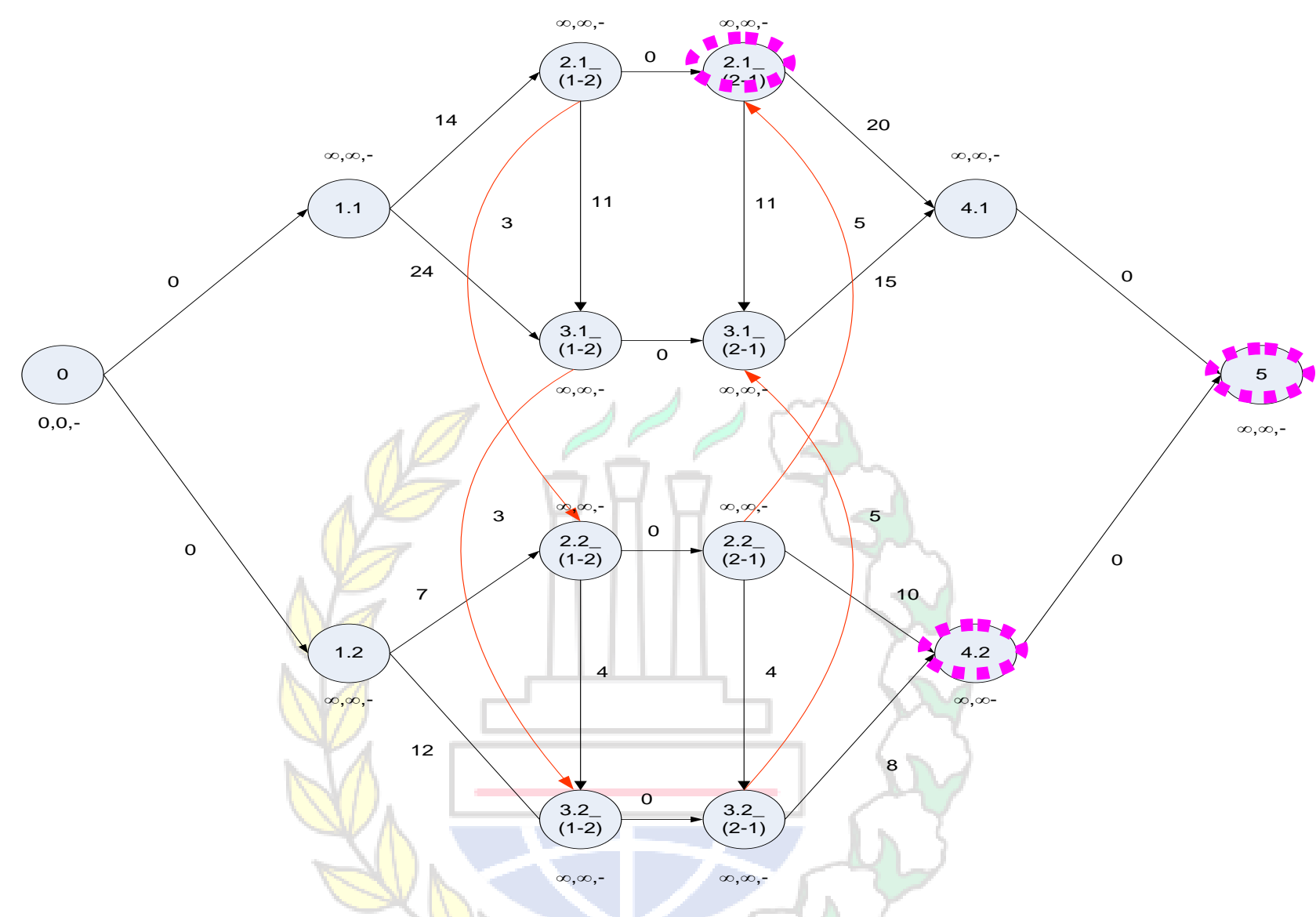

Gambar 3. Modifikasi Jaringan

Struktur jaringan yang dikembangkan adalah satu simpul asal dan satu simpul tujuan (one to one). Terdapat beberapa parameter yaitu waktu tempuh $t_{i j}$, biaya variabel kendaraan $c$, biaya tetap kendaraan $S$, biaya pergantian kendaraan $I$, biaya deteriorasi $D=V(t)$ dan biaya tunggu $w t$. Simpul $v \in V$ mempunyai waktu buka tutup (time window) $\left(a_{i}, b_{i}\right)$. Suatu lintasan dari simpul asal ke simpul lainnya dikatakan layak jika waktu kedatangan di simpul $i$, $\left(R_{i}\right)$ terjadi setelah waktu kedatangan di simpul tersebut dalam batas time window $\left(T_{i}=R_{i}\right)$. Jika waktu kedatangan terjadi sebelum waktu pelayanan di simpul tersebut maka kendaraan akan menunggu dan menimbulkan biaya tunggu $w(t)$. Jenis kendaraan bisa diganti pada saat kedatangan di suatu simpul $i$ dimana $i=N \backslash\{o, d\}$ untuk menghindari deteriorasi produk dengan biaya pergantian kendaraan $I\left(n_{1}, n_{2}\right)=I\left(m_{1}, m_{2}\right)$ jika pergantian kendaraan dari jenis kendaraan $m_{1}$ atau $I\left(n_{1}, n_{2}\right)=I\left(m_{2}, m_{1}\right)$ jika $\quad$ pergantian kendaraan dari jenis kendaraan $m_{2}$.

\subsection{Modifikasi Algoritma Dijkstra}

Karena permasalahan tidak bisa dimodelkan secara matematis sehingga menggunakan algoritma pemecahan masalah. Modifikasi Algoritma Dijkstra karena ada pergantian kendaraan sebagai strategi pengiriman produk perishable untuk meminimumkan total biaya dan mempertahankan kualitas produk sehingga membutuhkan lintasan kendaraan yang terpendek dari satu titik asal ke satu titik tujuan dengan dibatasi jendela waktu. Hasil modifikasi jaringan dapat dilihat pada Gambar 3. 
Modifikasi jaringan yaitu membuat duplikasi jaringan sehingga menjadi suatu jaringan yang terhubung satu sama lain. Setiap simpul mempunyai identitas masingmasing. Simpul $\mathbf{0}$ dan simpul 5 sebagai simpul delay untuk menghubungkan jaringan awal dengan jaringan yang diduplikasi. Penduplikasian jaringan digunakan untuk menggambarkan ada pergantian jenis kendaraan di titik antara. Simpul 1.1 melambangkan penggunaan jenis kendaraan 1 untuk simpul asal 1 begitu pula dengan 1.2 melambangkan penggunaan jenis kendaraan 2 untuk simpul 1. Untuk simpul antara terdapat garis berwarna merah yang menandakan diperbolehkan pergantian jenis kendaraan. Simpul tersebut diberi identitas 2.1_(1-2) artinya 2.1 melambangkan simpul 2 dengan jenis kendaraan 1 sedangkan (1-2) melambangkan pergantian kendaraan dari jenis kendaraan 1 ke jenis kendaraan 2 dan seterusnya.

\subsection{Asumsi-Asumsi Penelitian}

Asumsi yang digunakan adalah sebagai berikut:

1. Kendaraan berangkat dari satu simpul asal ke satu simpul tujuan.

2. Setiap simpul kecuali simpul asal dan simpul tujuan diperbolehkan terjadi pergantian kendaraan

3. Pergantian kendaraan yang diperbolehkan adalah truk dengan pesawat atau sebaliknya.

4. Kendaraan hanya bisa digunakan satu kali, apabila sepanjang lintasan dari titik asal ke titik tujuan terdapat lebih dari satu kali penggunaan jenis kendaraan yang sama maka kendaraan yang digunakan berbeda.

5. Pencarian rute terpendek kendaraan hanya untuk satu kali perjalanan.

6. Satu jenis kendaraan mempunyai biaya tetap dan biaya variabel kendaraan yang berbeda-beda.

7. Biaya pergantian kendaraan dari truk ke pesawat berbeda dengan biaya pergantian dari pesawat ke truk
8. Biaya deteriorasi produk merupakan biaya yang timbul akibat penurunan kualitas produk sepanjang perjalanan yang diasumsikan sama dengan fungsi deteriorasi $V(t)$, suatu fungsi terhadap waktu.

9. Biaya variabel kendaraan merupakan biaya yang dibutuhkan selama perjalanan tergantung pada durasi waktu dari titik $i$ ke titik $j, t_{i j}$.

Permasalahan menentukan rute terpendek dari titik asal ke titik tujuan dengan time window untuk pengangkutan produk perishable dimana produk mengalami deteriorasi selama perjalanan yang meminimumkan total biaya tidak dapat diformulasikan secara matematis sehingga variabel keputusan, fungsi tujuan, dan pembatas hanya bisa dituliskan secara verbal.

Variabel Keputusan

Dalam modifikasi Algoritma Dijkstra, variabel keputusan adalah lintasan dari simpul asal $o$ ke simpul simpul tujuan $d$ yang terpilih. Lintasan yang terpilih adalah lintasan dengan total biaya yang minimum dan memenuhi pembatas time window.

\section{Fungsi tujuan}

Meminimasi total biaya transportasi yang terdiri dari biaya tetap kendaraan, biaya variabel kendaraan, biaya pergantian kendaraan, dan biaya deteriorasi produk.

\section{Pembatas}

- setiap lintasan dari $i$ ke $j$ menggunakan kendaraan $m$ hanya terpilih satu kali

- tidak ada lintasan yang terputus

- tidak ada lintasan yang kembali (memutar)

- $\quad$ simpul $j$ dikunjungi tepat setelah simpul $i$, waktu keberangkatan di simpul $i\left(R_{i}\right)$ terjadi setelah waktu kedatangan $T_{i}$ di simpul $i$

- waktu keberangkatan di setiap simpul dalam batas time window 
- Pembatas biner yaitu pembatas variabel keputusan yaitu lintasan yang terpilih

\subsection{Prosedur Pemecahan Masalah}

Proses Algoritma Dijkstra adalah proses pemberian label semua simpul pada graf dengan salah satu label temporer (sementara) atau label permanen (tetap). Label temporer untuk suatu simpul adalah label yang menunjukkan batas atas bobot lintasan dari simpul sumber $v_{1}$ ke simpul $v_{i} \in V$. Label permanen untuk simpul $v_{i} \in V$ adalah label yang menunjukkan bobot lintasan terpendek/bobot yang terkecil dari simpul sumber $v_{1}$ ke simpul $v_{i}, \in V$. Label untuk setiap titik $i \in N$ ada tiga yang dinyatakan dengan notasi $c_{i}, u_{i}, w_{i}$. Notasi $c_{i}$ menunjukkan total akumulasi biaya pada titik $i$, notasi $u_{i}$ menunjukkan total akumulasi waktu pada titik $i$, sedangkan $w_{i}$ menunjukkan titik pendahulu dimana titik $i$ dicapai. Himpunan titik yang sudah dinyatakan permanen adalah $M$ dan himpunan titik yang belum dinyatakan permanen adalah $M^{\prime}$. Proses pelabelan dilakukan sampai semua simpul mendapatkan label permanen. Prosedur algoritma berhenti jika simpul tujuan sudah dinyatakan permanen.

Beberapa notasi yang digunakan dalam prosedur pemecahan masalah dengan modifikasi Algoritma Dijkstra adalah sebagai berikut:

\section{Indeks}

$\begin{array}{lll} & i, j \quad: & \text { indeks simpul asal, simpul } \\ & & \text { tujuan }(i, j \in N) \\ k & : & \text { indeks simpul } \\ & \text { persimpangan }(N= \\ & & k \backslash\{o, d\}) \\ & : & \text { simpul awal } \\ o & : \text { simpul akhir } \\ d & : \text { jenis kendaraan yang } \\ m & & \text { tersedia }\end{array}$

Himpunan

M
: himpunan titik yang sudah dilabel
$M^{\prime}$
: himpunan titik yang belum dilabel
V $\quad$ : himpunan simpul

\section{Parameter}

$a_{i}$

$b_{i} \quad:$ batas atas time window

$S_{o k i}^{m}$

: biaya tetap kendaraan dari simpul awal $o$ ke simpul $i$ melewati simpul $k$ dengan kendaraan $m$

: biaya tetap kendaraan dari simpul awal $o$ ke simpul $i$ melewati simpul $k$ dengan kendaraan $m$ sebelum simpul $i$ dicapai

: biaya tetap kendaraan dari simpul asal $o$ ke simpul $k$ dengan kendaraan $m$

: Biaya tetap kendaraan dari simpul $k$ ke simpul $i$ dengan kendaraan $m$

$I\left(m_{1}, m_{2}\right)$ : biaya pergantian kendaraan dari jenis kendaraan 1 ke jenis kendaraan 2

$I\left(m_{2}, m_{1}\right)$ : Biaya pergantian kendaraan dari jenis kendaraan 2 ke jenis kendaraan 1

: waktu tempuh dari simpul awal $o$ ke simpul $i$ melewati simpul $k$

$t_{o k} \quad:$ waktu tempuh dari simpul $\begin{array}{ll} & \text { awal } o \text { ke simpul } k \\ t_{k i} & \text { : waktu tempuh dari simpul }\end{array}$ $t_{k i} \quad k$ ke simpul $i$

$w s\left(m_{1}, m_{2}\right)$ : waktu proses pergantian kendaraan dari jenis kendaraan 1 ke jenis kendaraan 2

$w s\left(m_{2}, m_{1}\right)$ : waktu proses pergantian kendaraan dari jenis kendaraan 2 ke jenis kendaraan 1

\section{Variabel}

$D_{o i}$

: biaya deteriorasi produk dari simpul awal $o$ ke 


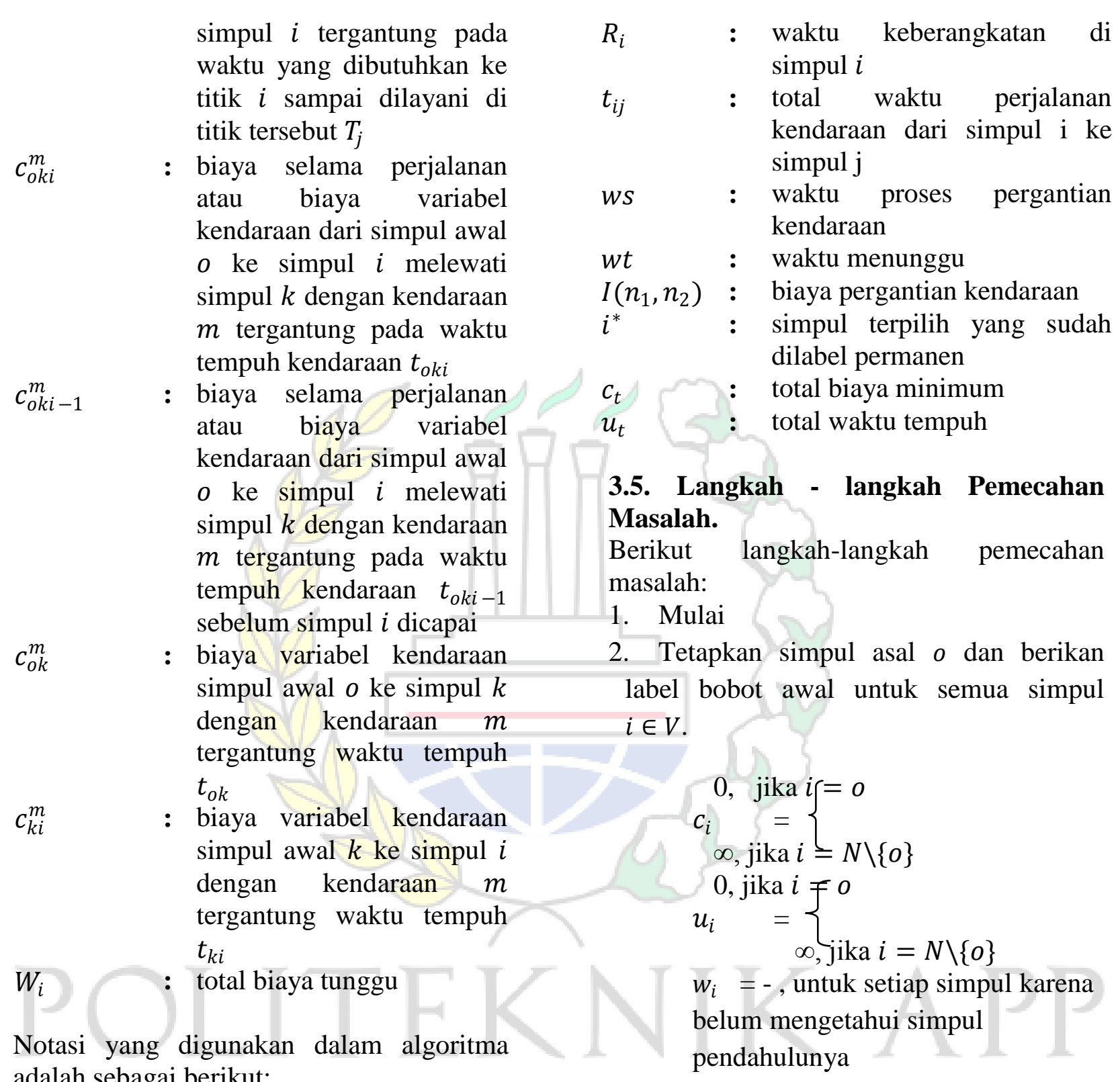

adalah sebagai berikut:

\begin{tabular}{lll}
\multicolumn{1}{c}{ Notasi } & & \\
$c_{i}$ & $:$ & total akumulasi biaya pada \\
& titik $i$ \\
$u_{i}$ & $:$ & total akumulasi waktu pada \\
& titik $i$ \\
$w_{i}$ & $:$ & titik pendahulu dimana titik $i$ \\
& dicapai \\
$c_{i}^{\prime}$ & $:$ & total akumulasi biaya pada \\
& titik $i$ yang diperbarui \\
$u_{i}^{\prime}$ & $:$ & total $I\left(m_{1}, m_{2}\right)$, \\
& titik pergantian dari jika \\
$w_{i}^{\prime}$ & $:$ & titik kendaraan 1 ke jenis \\
& dicar kendaraan 2 \\
$T_{i}$ & $:$ & waktu kedatangan di simpul $i$
\end{tabular}

3. Tetapkan $M$ untuk simpul yang sudah dilabel permanen dan $M^{\prime}$ untuk simpul yang belum dilabel permanen $M^{\prime}=$ $N\{k\}$ dimana $k=o$

4. Identifikasi simpul $i$ yang berhubungan langsung dengan $\mathrm{k}$ untuk tiap $i \in M^{\prime}$, dan cek apakah ada pergantian jenis kendaraan dari simpul $k$ ke simpul $i$.

Jika ya, maka biaya pergantian kendaraan:

$$
I\left(n_{1}, n_{2}\right)=\left\{\begin{array}{llr}
I\left(m_{1}, m_{2}\right), & & \text { jika } \\
\text { pergantian dari } & \text { jenis } \\
\text { kendaraan 1 ke } & \text { jenis } \\
\text { kendaraan 2 } & & \\
& & \\
I\left(m_{2}, m_{1}\right), & & \text { jika } \\
\text { pergantian dari } & \text { jenis } \\
\text { kendaraan 2 ke } & \text { jenis } \\
\text { kendaraan 1 } &
\end{array}\right.
$$


Jika tidak, $I\left(n_{1}, n_{2}\right)=0, \quad$ artinya kendaraan yang digunakan masih sama, kemudian lanjut ke langkah 5

5. Tetapkan waktu kedatangan di simpul $j$ $T_{j}=R_{i}+t_{i j}$

Jika di simpul $j$ merupakan simpul dimana terjadi pergantian kendaraan maka

$$
\begin{aligned}
& T_{j}=R_{i}+w s+t_{i j} \\
& w s=\left\{\begin{array}{l}
w s\left(m_{1}, m_{2}\right), \text { jika pergantian } \\
\text { dari } m_{1} \text { ke } m_{2} \\
w s\left(m_{2}, m_{1}\right), \text { jika pergantian } \\
\text { dari } m_{2} \text { ke } m_{1}
\end{array}\right.
\end{aligned}
$$

Lanjutkan ke langkah 6

6. Cek apakah waktu kedatangan di simpul $i \quad\left(T_{i}\right)$ sudah sesuai dengan waktu pelayanan di simpul tersebut? Jika,

$$
a_{i} \leq T_{i} \leq b_{i}
$$

keberangkatan tersebut $\left(R_{i}\right)=T_{i}$

maka
untuk $\begin{array}{r}\text { waktu } \\ \text { simpul }\end{array}$

$T_{i}<a_{i}$ maka waktu keberangkatan di simpul tersebut, $R_{i}=a_{i}$

$T_{i}>b_{i}$ maka waktu kedatangan di simpul $i$ tersebut infeasible

Lanjut ke langkah 7

7. Cek, apakah ada waktu menunggu dari $k$ ke $i$ ?

jika ya, hitung lama waktu menunggu yaitu $w_{t}=R_{i}-T_{i}$

jika tidak, $w_{t}=0$, kemudian lanjut ke langkah 8

8. Hitung waktu tempuh dari simpul asal o ke simpul $i$ dengan simpul antara $k$ $\left(t_{o k i}\right), t_{o k i}=t_{o k}+t_{k i}$ dan lanjut ke langkah 9.

9. Hitung biaya variabel kendaraan , $c_{o k i}^{m}$ yaitu biaya variabel kendaraan per satuan waktu. Waktu yang digunakan adalah waktu tempuh sehingga $c_{o k i}^{m}=$ c. $t_{i j}$. Kemudian lanjut ke langkah 10.

10. Hitung biaya deteriorasi, $D_{o i}$ yang diasumsikan sebanding dengan fungsi deteriorasi produk terhadap waktu $D_{o i}=$ $V(t)$ sehingga nilai fungsi deteriorasi menjadi biaya deteriorasi.Lanjut ke langkah selanjutnya.

11. Tetapkan total biaya transportasi kendaraan dari simpul asal $o$ ke simpul $i$

$$
c_{i}^{\prime}=S_{o k i}^{m}+c_{o k i}^{m}+I\left(n_{1}, n_{2}\right)+D_{o i}
$$

- Jika, simpul $i$ merupakan simpul pergantian kendaraan maka biaya transportasi kendaraan adalah: $c_{i}^{\prime}=S_{o k i-1}^{m}+c_{o k i-1}^{m}+I\left(n_{1}, n_{2}\right)+$ $D_{o i}$

Jika, simpul $k$ merupakan simpul terjadi pergantian kendaraan maka biaya transportasi di simpul $i$ adalah: $c_{i}^{\prime}=S_{o k}^{m}+S_{k i}^{m}+c_{o k}^{m}+$ $c_{k i}^{m}+I\left(n_{1}, n_{2}\right)+D_{o i}$ lanjut ke langkah selanjutnya

12. Perbarui label simpul $i$ jika: $c_{i}^{\prime}<c_{i}$ maka label di simpul $i$ diganti dengan $c_{i}^{\prime}$

$c_{i} \geq c_{i}$ maka label di simpul $i$ tetap, $c_{i}$

13. Cari titik $i \in M^{\prime}$ yang memiliki $c_{i}^{\prime}$ paling kecil. Misal $i^{*}$ titik terpilih.

Jika $i^{*} \neq d$ tetapkan $k=i^{*}$ dan perbarui $M=M \cup\{k\}$ dan $M^{\prime}=$ $M^{\prime}\{k\}$, kembali ke langkah 3 .

- Jika $i^{*}=d$, lanjutkan ke langkah 14.

14. Tetapkan total biaya transportasi minimum, $c_{t}$, Lintasan optimal diperoleh melalui penelusuran balik melalui dari titik tujuan $d$ berdasarkan informasi $w_{i}$. Kemudian lanjutkan ke langkah 15.

15. Hitung total biaya tunggu pada lintasan yang terpilih, $W_{i}=w(t) \times \sum w t_{i}$, lanjut ke langkah selanjutnya.

16. Hitung total biaya perjalanan yaitu total biaya transportasi kendaraan dan biaya tunggu dari simpul $i$ ke $j$ pada lintasan yang terpilih, $T C=c_{i}^{\prime}+W_{i}$

17. Selesai.

\subsection{Verifikasi Algoritma}

Verifikasi algoritma dilakukan dengan membandingkan hasil perhitungan numerik 
secara manual dengan hasil perhitungan menggunakan sofware LINGO. Software LINGO digunakan untuk menguji apakah formulasi matematis pada Algoritma Dijkstra yang dimodifikasi sudah terverifikasi atau belum.

Verifikasi formulasi dilakukan untuk menjamin bahwa formulasi yang dikembangkan untuk perhitungan yang digunakan dalam algoritma konsisten secara logis.

Untuk pengujian secara manual, lintasan yang terpilih dari hasil perhitungan secara manual adalah 1-3-8-9-5-12-14 dengan total biaya 289 dapat dilihat pada Gambar 4 .
Hasil pengujian modifikasi algoritma Dijkstra dengan menggunakan software LINGO sama dengan lintasan terpilih dengan perhitungan secara manual yaitu 13-8-9-5-12-14 dengan total biaya 289 yang ditunjukkan pada Tabel 2.

Berdasarkan hasil kedua pengujian tersebut, diperoleh lintasan terpilih yang sama. Oleh karena itu, modifikasi Algoritma Dijkstra dapat dikatakan terverifikasi.

\subsection{Contoh Numerik}

Contoh numerik dilakukan dengan menggunakan data hipotetik. Jaringan transportasi dari permasalahan dapat dilihat pada Gambar 5.

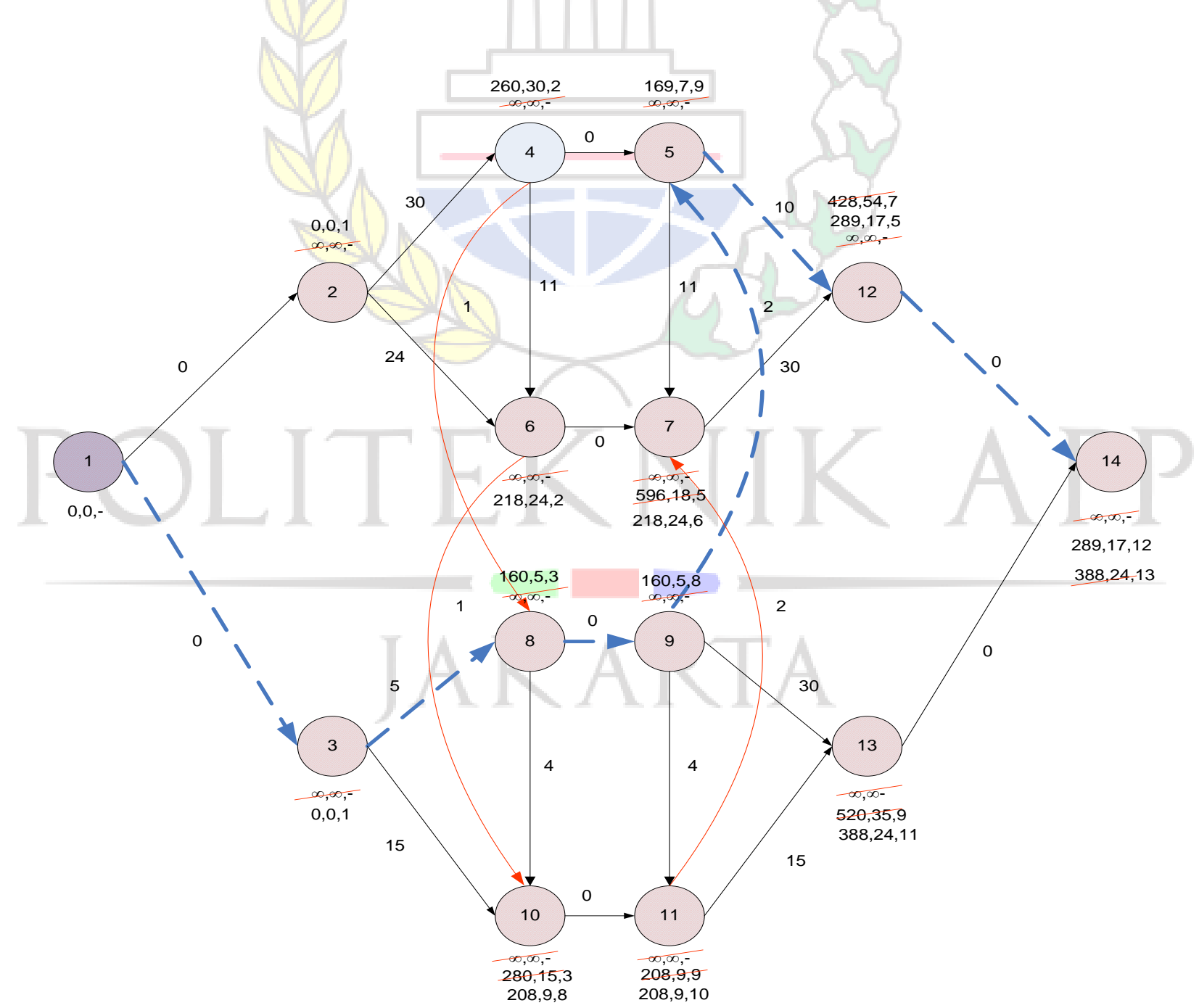

Gambar 4. Lintasan terpilih hasil perhitungan secara manual (verifikasi model) 
Ada dua jenis kendaraan yang digunakan yaitu $m_{1}$ untuk truk dan $m_{2}$ untuk pesawat. Fungsi deteriorasi yang digunakan adalah non linier, $D(t)=t^{2}$. Data hipotetik yang digunakan dapat dilihat pada Tabel 3.

Dengan menggunakan modifikasi Algoritma Dijkstra, perhitungan dilakukan secara iteratif. Langkah awal perhitungan adalah penyederhanaan nomor simpul.
Kemudian menetapkan simpul 1 sebagai simpul awal $o$. Langkah selanjutnya adalah menetapkan titik yang termasuk himpunan $M$ yaitu titik yang sudah dilabel permanen dengan bobot nilai terkecil. Iterasi berakhir apabila semua titik sudah diberi label permanen sehingga dapat dihitung biaya total perjalanan.

Tabel 2. Hasil perhitungan dengan LINGO

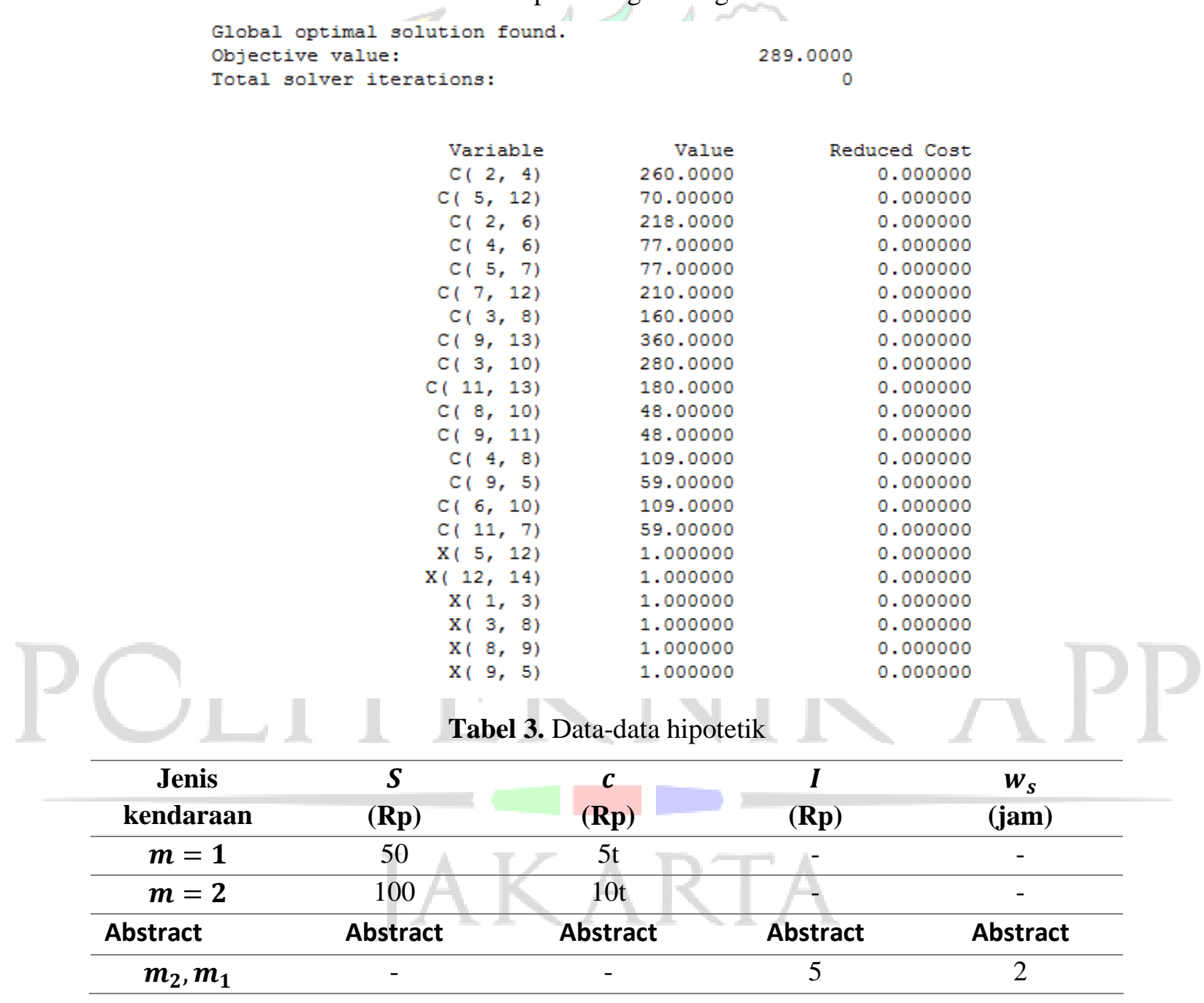

1. Jenis kendaraan $(m)$

Jenis kendaraan pertama dan jenis kendaraan kedua dibedakan berdasarkan kecepatan dimana $m_{1}<m_{2}$ artinya jenis kendaraan kedua lebih cepat dari jenis kendaraan pertama.

2. Biaya tetap kendaraan $(S)$
Biaya tetap kendaraan adalah biaya yang dikeluarkan untuk kendaraan dimana nilainya tetap sepanjang perjalanan dari simpul asal ke simpul tujuan.

3. Biaya variabel kendaraan $(c)$

Biaya perjalanan kendaraan merupakan biaya yang dikeluarkan 
selama perjalanan tergantung pada waktu tempuh kendaraan dari simpul asal ke simpul tujuan

4. Biaya pergantian kendaraan $(I)$ Biaya pergantian kendaraan dikeluarkan ketika terjadi pergantian jenis kendaraan.
5. Waktu proses pergantian kendaraan $(w s)$

Waktu proses pergantian kendaraan merupakan waktu yang dibutuhkan untuk mengganti jenis kendaraan.

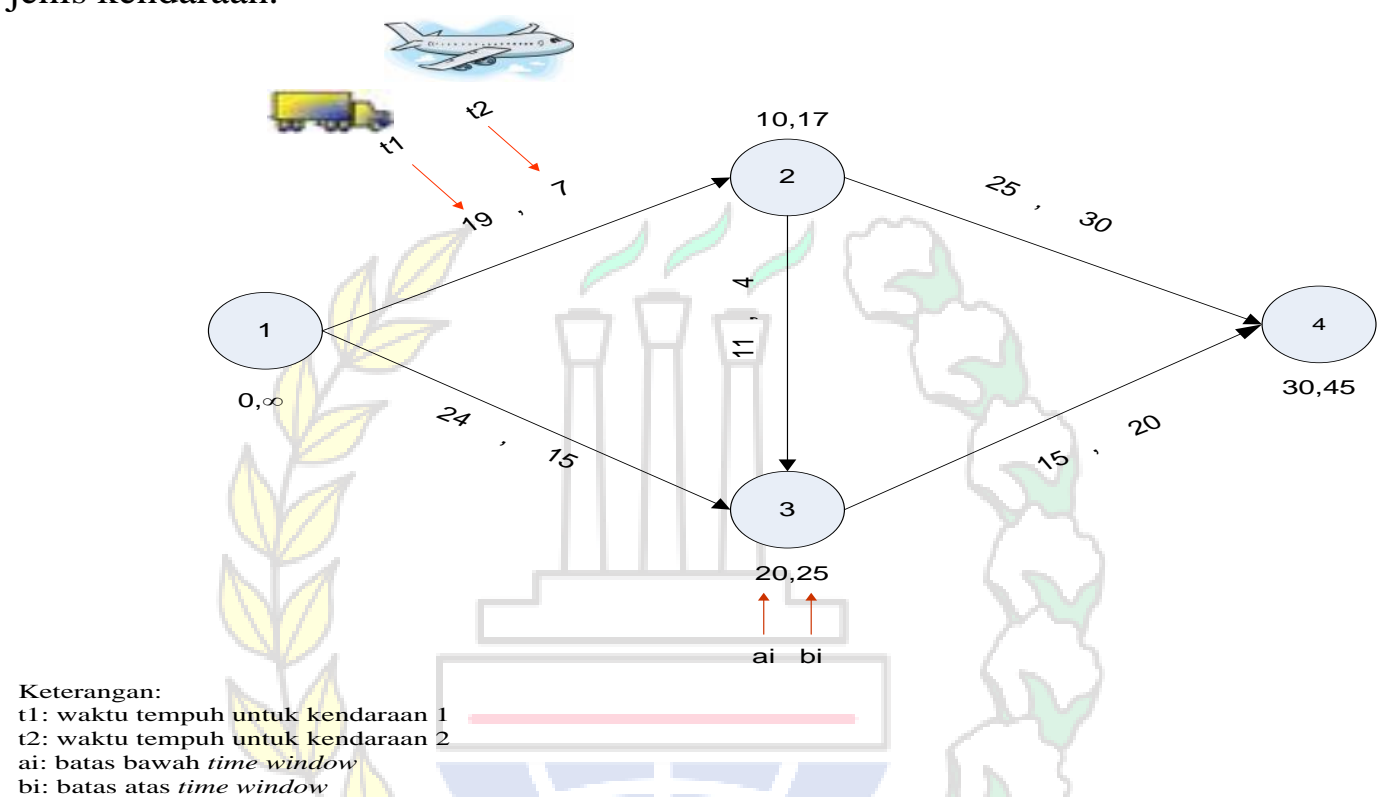

bi: batas atas time window

Gambar 5 Jaringan Transportasi

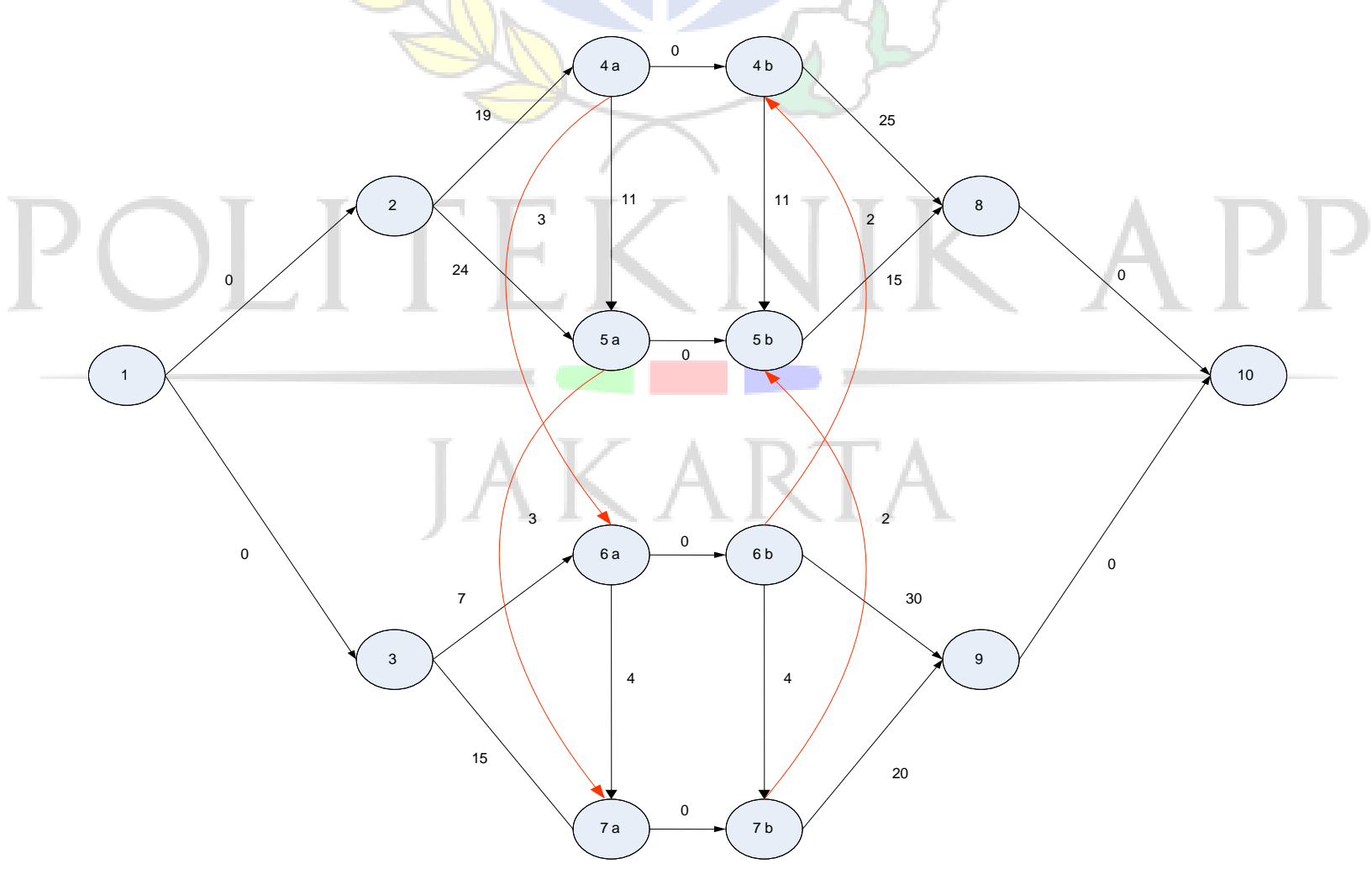

Gambar 6. Replikasi Jaringan 
Untuk pengujian modifikasi Algoritma Dijkstra terlebih dahulu membuat replikasi jaringan seperti Gambar 6. Replikasi jaringan dilakukan dengan membuat duplikasi jaringan sehingga menjadi suatu jaringan yang terhubung satu sama lain. Selanjutnya langkah penyelesaian masalah sebagai berikut:

\section{Langkah 0}

Memberikan label awal untuk setiap simpul dan menetapkan simpul asal $o$. Simpul asal $o$ adalah simpul 1. Simpul 1 diberi label 0 dan simpul lain $\infty$. Label-awal untuk masing-masing simpul dapat dilihat pada Tabel 4.

Tabel 4. Pelabelan awal simpul

\begin{tabular}{c|c|c|c|}
\hline $\operatorname{simpul}(\boldsymbol{i})$ & $\boldsymbol{c}_{\boldsymbol{i}}$ & $\boldsymbol{u}_{\boldsymbol{i}}$ & $\boldsymbol{w}_{\boldsymbol{i}}$ \\
\hline $\mathbf{1}$ & 0 & 0 & - \\
\hline $\mathbf{2}$ & $\infty$ & $\infty$ & - \\
\hline $\operatorname{simpul}(\boldsymbol{i})$ & $\boldsymbol{c}_{\boldsymbol{i}}$ & $\boldsymbol{u}_{\boldsymbol{i}}$ & $\boldsymbol{w}_{\boldsymbol{i}}$ \\
\hline $\mathbf{3}$ & $\infty$ & $\infty$ & - \\
\hline $\mathbf{4 a}$ & $\infty$ & $\infty$ & - \\
\hline $\mathbf{4 b}$ & $\infty$ & $\infty$ & - \\
\hline $\mathbf{5 a}$ & $\infty$ & $\infty$ & - \\
\hline $\mathbf{5 b}$ & $\infty$ & $\infty$ & - \\
\hline $\mathbf{6 a}$ & $\infty$ & $\infty$ & - \\
\hline $\mathbf{6 b}$ & $\infty$ & $\infty$ & - \\
\hline $\mathbf{7 a}$ & $\infty$ & $\infty$ & - \\
\hline $\mathbf{7 b}$ & $\infty$ & $\infty$ & - \\
\hline $\mathbf{8}$ & $\infty$ & $\infty$ & - \\
\hline $\mathbf{9}$ & $\infty$ & $\infty$ & - \\
\hline $\mathbf{1 0}$ & $\infty$ & $\infty$ & - \\
\hline
\end{tabular}

\section{Langkah 1}

Menetapkan titik yang sudah dilabel $M=\{o\}$ dan $M^{\prime}=N \backslash\{k\}$ sehingga $k=o$

Titik yang termasuk himpunan $M$ merupakan titik yang sudah dilabel permanen yang bobot nilai terkecil Contoh: $M=1$ dan $k=1$.

\section{Langkah 2}

Identifikasi simpul $i \in M^{\prime} \quad$ yang berhubungan langsung dengan $k$.

Contoh: Simpul $i$ yang berhubungan langsung dengan simpul 1 adalah simpul 2 dan simpul 3.
Setelah menetukan simpul $i$ dan cek apakah dari simpul k ke simpul $i$ ada pergantian kendaraan atau tidak. Karena simpul 1 merupakan simpul asal maka tidak ada pergantian kendaraan sehingga $I\left(n_{1}, n_{2}\right)=$ 0 . Hasil identifikasi langkah 2 dapat dilihat pada Tabel 5.

Tabel 5. Identifikasi simpul $i$ yang berhubungan langsung dengan $k$

\begin{tabular}{ccc}
\hline $\boldsymbol{k}$ & $\boldsymbol{i}$ & $\boldsymbol{I}\left(\boldsymbol{n}_{\mathbf{1}}, \boldsymbol{n}_{\mathbf{2}}\right)$ \\
\hline $\mathbf{1}$ & 2 & 0 \\
\hline & 3 & 0 \\
\hline
\end{tabular}

Jika terjadi pergantian kendaraan pada simpul $i$ yang terhubung dengan $k$ dimana $k \neq o$ maka $I\left(n_{1}, n_{2}\right)=I\left(m_{1}, m_{2}\right)$ jika terjadi pergantian kendaraan dari $m_{1}$ ke $m_{2}$ atau $I\left(n_{1}, n_{2}\right)=I\left(m_{2}, m_{1}\right)$ jika terjadi pergantian kendaraan dari $m_{2}$ ke $m_{1}$.

\section{Langkah 3}

Menghitung waktu kedatangan di titik $i,\left(T_{i}\right)$

Contoh :

Misal dipilih simpul 1-3-6 dan waktu kedatangan di simpul 1-3-6a adalah:

- waktu kedatangan di simpul 3

$T_{3}=T_{1}+t_{13}$

$T_{1}=0, t_{13}=0$ maka

$T_{3}=0+0=0$

- waktu kedatangan di simpul 6

$T_{6}=T_{3}+t_{36}$

$T_{3}=0, t_{36}=7$

$T_{6}=0+7=7$

\section{Langkah 4}

Melakukan pengecekan waktu kedatangan di simpul $i$ apakah sudah sesuai dengan waktu pelayanan di simpul tersebut $T_{i}$.

Contoh:

$a_{6}=10, b_{6}=15$ maka waktu kedatangan di simpul 6 sampai dilayani adalah $T_{6}=7$ karena $T_{6} \leq a_{6}$ maka waktu keberangkatan $R_{6}$ adalah 10

Berikut tabel 6 perhitungan untuk langkah 3 dan langkah 4 
Tabel 6 perhitungan waktu kedatangan di simpul $\boldsymbol{i}$

\begin{tabular}{cccccc}
\hline $\boldsymbol{k}$ & $\boldsymbol{i}$ & $\boldsymbol{u}$ & $\boldsymbol{t}_{\boldsymbol{i} \boldsymbol{j}}$ & $\boldsymbol{T}_{\boldsymbol{i}}$ & $\boldsymbol{R}_{\boldsymbol{i}}$ \\
\hline $\mathbf{3}$ & 6 & 0 & 7 & 7 & 10 \\
\hline
\end{tabular}

\section{Langkah 5}

Menghitung waktu menunggu (wt)

Contoh: $w t_{6}=R_{6}-T_{6}=10-7=3$, karena waktu kedatangan di titik 6 lebih awal dari waktu pelayanan di titik tersebut sehingga waktu menunggu atau $w t_{6}=3$

\section{Langkah 6}

Menghitung waktu perjalanan $\left(T_{o k i}\right)$.

Contoh :

waktu tempuh dari titik 3 ke titik 9. Untuk menuju titik 3 melewati titik 6 maka waktu tempuh adalah:

$$
\begin{gathered}
T_{369}=R_{6}+t_{69}=10+30 \\
=40 \\
R_{9}=40 \mathrm{karena} a_{9} \leq R_{9} \leq b_{9} \\
\text { atau } 30 \leq R_{9} \leq 40 \text { maka } \\
w t_{9}=40-40=0 \\
t_{369}=t_{36}+t_{69}=7+30=37 \\
\sum w=w t_{6}+w t_{9}=3+0=3
\end{gathered}
$$

\section{Langkah 7}

Menghitung biaya transportasi kendaraan. Contoh: biaya transportasi di simpul 9 adalah

$$
\begin{gathered}
c_{9}^{\prime}=S_{369}^{2}+c_{369}^{2}+I\left(n_{1}, n_{2}\right)+D_{369} \\
=100+(10 \times 37)+0 \\
+40^{2}=2070
\end{gathered}
$$

\section{Langkah 8}

Memperbarui label di simpul $i, c_{i}^{\prime}$

Contoh: label baru untuk titik 9 adalah $c_{9}^{\prime}=$ 2070 dan $u_{9}^{\prime}=40$.

Berikut contoh memperbarui label di titik $i$ pada Tabel 7.

Tabel 7. contoh perbarui label di simpul $\boldsymbol{i}$

\begin{tabular}{cccccccc}
\hline $\boldsymbol{k}$ & $\boldsymbol{i}$ & $\boldsymbol{c}_{\boldsymbol{i}}$ & $\boldsymbol{u}_{\boldsymbol{i}}$ & $\boldsymbol{w}_{\boldsymbol{i}}$ & $\boldsymbol{c}_{\boldsymbol{i}}^{\prime}$ & $\boldsymbol{u}_{\boldsymbol{i}}^{\prime}$ & $\boldsymbol{w}_{\boldsymbol{i}}^{\prime}$ \\
\hline 6 & 9 & $\infty$ & $\infty$ & - & 2070 & 40 & 6
\end{tabular}

\section{Langkah 9}

Mengidentifikasi $i$ yang belum di label permanen, jika

- $\quad i \neq d$ maka lanjutkan ke langkah 2

- $\quad i=d$ maka lanjutkan ke langkah 10

Karena masih ada simpul yang belum dilabel permanen maka perhitungan kembali ke langkah 2.

\section{Langkah 10}

Menetapkan total biaya transportasi yang minimum dan menentukan lintasan dengan biaya minimum dengan penelusuran balik. Untuk perhitungan ini, lintasan terpendek adalah 10-8-5b-7b-7a-6a-3-1 dengan total biaya transportasi 1784 .

\section{Langkah 11}

Menghitung biaya tunggu. dalam pengujian biaya tunggu tergantung pada lama waktu menunggu dimana $W_{i}=4 t$

Contoh: biaya tunggu pada lintasan yang terpilih 1-3-6a-7a-7b-5b-8-10 adalah 36 maka total biaya tunggu $W_{i}=4 \times 9=36$

\section{Langkah 12}

Menghitung biaya total perjalanan yaitu total biaya transportasi dan biaya tunggu

Contoh:

TC untuk lintasan yang terpilih $=$ $1784+36=1820$.

3.8 Hasil akhir perhitungan

Berdasarkan langkah-langkah perhitungan maka diperoleh hasil sebagai berikut:

1. Rute kendaraan terpilih adalah lintasan:1-3-6a-7a-7b-5b-8-10 yang diilustrasikan pada gambar 7. Lintasan yang terpilih adalah lintasan yang dilalui oleh jenis kendaraan $m=2$, kemudian pada simpul $7 b-5 b$ terjadi pergantian jenis kendaraan $m=1$ sehingga lintasan ini dapat meminimumkan biaya transportasi.

2. Total biaya kendaraan untuk rute terpilih adalah $\mathrm{Rp} 1820$ yaitu total biaya kendaraan Rp 1784 dan biaya tunggu Rp 36. 
3. Total waktu perjalanan kendaraan adalah 37 jam yaitu waktu tempuh kendaraan 26 jam, waktu tunggu 9 jam,

dan waktu pergantian kendaraan 2 jam yang diilustrasikan pada tabel 9.

Tabel 8. Total biaya transportasi dan total biaya perjalanan untuk rute terpilih

\begin{tabular}{ccccccccc}
\hline $\boldsymbol{i}$ & $\boldsymbol{j}$ & $\boldsymbol{S}$ & $\boldsymbol{c}$ & $\boldsymbol{I}$ & $\boldsymbol{D}$ & $\boldsymbol{c}^{\prime}$ & $\boldsymbol{W}_{\boldsymbol{i}}$ & $\boldsymbol{T C}$ \\
\hline $\mathbf{1}$ & 3 & 0 & 0 & 0 & 0 & 0 & 0 & 0 \\
\hline $\mathbf{3}$ & $6 \mathrm{a}$ & 100 & 70 & 0 & 100 & 270 & 12 & 270 \\
\hline $\mathbf{6 a}$ & $7 \mathrm{a}$ & 100 & 110 & 0 & 400 & 610 & 24 & 610 \\
\hline $\mathbf{7 a}$ & $7 \mathrm{~b}$ & 100 & 110 & 0 & 400 & 610 & 0 & 610 \\
\hline $\mathbf{7 b}$ & $5 \mathrm{~b}$ & 100 & 110 & 5 & 484 & 699 & 0 & 699 \\
\hline $\mathbf{5 b}$ & 8 & 150 & 260 & 5 & 1369 & 1784 & 0 & 1784 \\
\hline $\mathbf{8}$ & 10 & 150 & 260 & 5 & 1369 & 1784 & 0 & 1784 \\
\hline & $1-3-6 a-7 a-7 b-5 b-8-10$ & & & $\mathbf{1 7 8 4}$ & $\mathbf{3 6}$ & $\mathbf{1 8 2 0}$ \\
\hline
\end{tabular}

Tabel 9. Total waktu perjalanan kendaraan

\begin{tabular}{c|c|c|c}
\hline Simpul asal $(\boldsymbol{i})$ & Simpul tujuan $(\boldsymbol{j})$ & Waktu keberangkatan $(\boldsymbol{i})$ & $\begin{array}{c}\text { Waktu kedatangan } \\
(\boldsymbol{j})\end{array}$ \\
\hline $\mathbf{1}$ & 3 & 00.00 & 00.00 \\
\hline $\mathbf{3}$ & $6 \mathrm{a}$ & 00.00 & 07.00 \\
\hline $\mathbf{6 a}$ & $7 \mathrm{a}$ & 10.00 & 20.00 \\
\hline $\mathbf{7 a}$ & $7 \mathrm{~b}$ & 20.00 & 20.00 \\
\hline $\mathbf{7 b}$ & $5 \mathrm{~b}$ & 20.00 & 22.00 \\
\hline $\mathbf{5 b}$ & 8 & 22.00 & 37.00 \\
\hline $\mathbf{8}$ & 10 & 37.00 & 37.00 \\
\hline
\end{tabular}

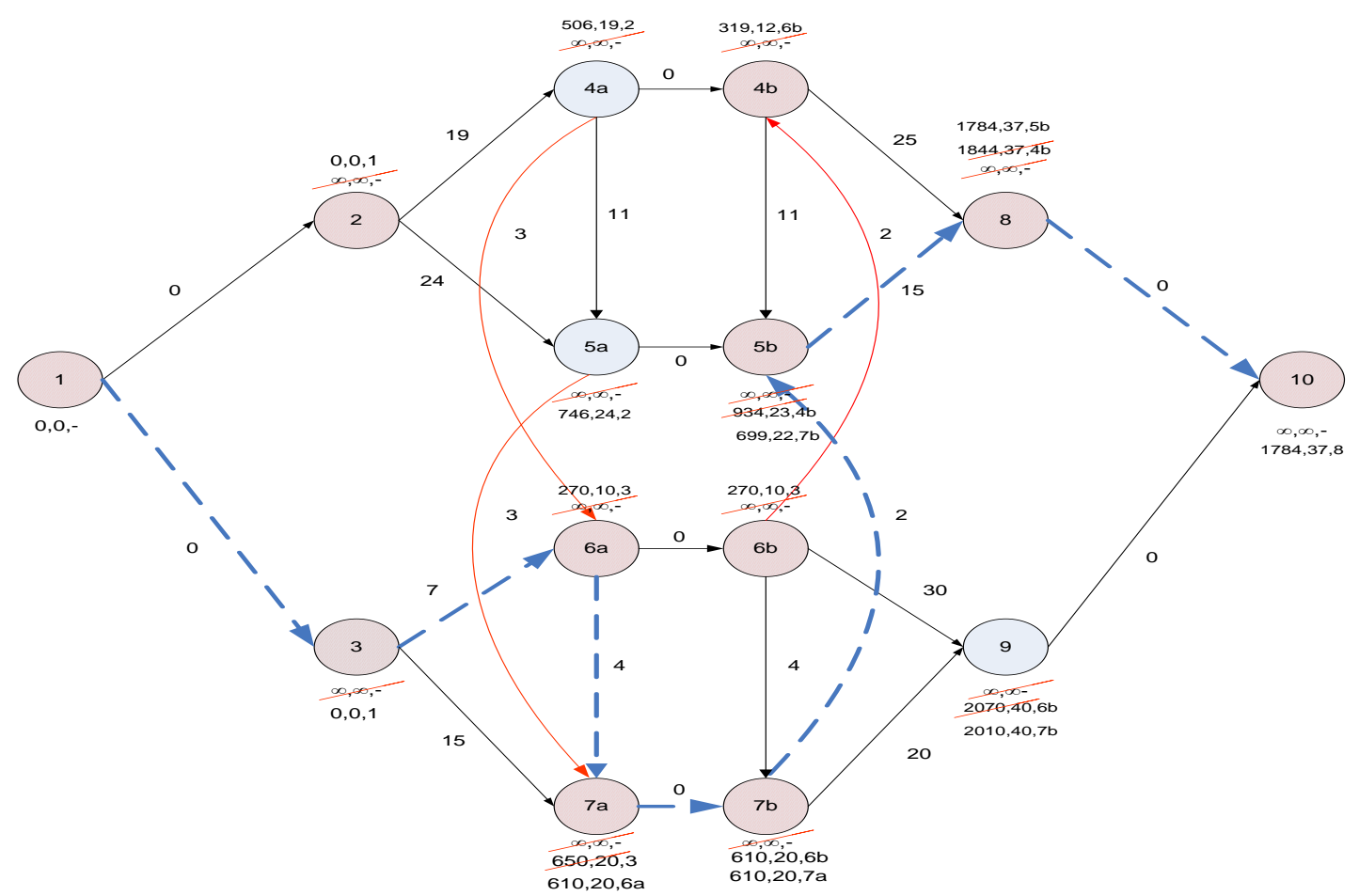

Gambar 7. Rute Terpilih

Page $\mid 70$ 


\section{KESIMPULAN}

Rute yang terpilih adalah rute dengan pergantian kendaraan yaitu pertama menggunakan jenis kendaraan 2 (kendaraan dengan waktu tempuh lebih singkat tapi biaya kendaraan lebih mahal) kemudian pada suatu simpul terjadi pergantian kendaraan dengan jenis kendaraan 1 (kendaraan dengan waktu tempuh lebih lama tapi biaya kendaraan lebih murah) sehingga meminimumkan total biaya transportasi. Pergantian kendaraan dapat menjadi suatu strategi untuk meminimalkan biaya total perjalanan pengangkutan produk perishable sampai ke titik-tujuan. Strategi ini di samping mempertimbangkan biaya yang efektif juga meminimalisasi penurunan kualitas produk sehingga masih mempunyai nilai ekonomis pada saat tiba di konsumen. Biaya deteriorasi berkontribusi memperbesar total biaya sehingga dibutuhkan penentuan lintasan kritis untuk mempercepat waktu aktivitas pengangkutan produk perishable.

Model transportasi pengiriman produk perishable dengan multi moda belum sepenuhnya menggambarkan kondisi sesungguhnya karena masih menggunakan data hipotetik. Dengan menggunakan data hipotetik, pengujian terhadap modifikasi Algoritma Dijkstra dapat dilakukan sehingga diperoleh rute kendaraan yang menjadi variabel keputusan.

Berdasarkan keterbatasan penelitian ini, penelitian selanjutnya dapat menggunakan data riil. Penggunaan data riil untuk pengujian modifikasi Algoritma Dijkstra memberikan hasil pengujian yang valid terhadap sistem nyata (real system).

Di samping itu, model ini dapat dikembangkan dengan melibatkan lebih banyak titik asal dan titik tujuan distribusi atau menambahkan jumlah jenis kendaraan lebih dari dua.

\section{DAFTAR PUSTAKA}

[1] J. Chen, M. Dong dan L. Xu, "A perishable product shipment consolidation model considering freshness - keeping effort," Transportation Research Part E, pp. 56-86, 2018.

[2] L. Trihardani, Pengembangan Model Distribusi Produk Perishable Multi Temperatur dengan Mempertimbangkan Biaya Energi, Surabaya: Institut Teknologi Sepuluh November, 2011.

[3] A. T. Atmojo, Desain Konseptual Pola Pengangkutan Sayur Antar Pulau, Surabaya: Institut Teknologi Sepuluh Nopember, 2010.

[4] A. Nazemi dan F. Omdi, "An efficient dynamic model for solving the shortest path problem," Transportation Research part C, vol. 26, pp. 1-19, 2013.

[5] Z.-J. Ma, Y. Wu dan Y. Dai, "A combined order selection and timedependent vehicle routing problem with time widows for perishable product delivery," Computer \& Industrial Engineering, vol. 114, pp. 101-113, 2017.

[6] I. Sartika, Pengembangan Model Rantai Pasok Produk Mudah Rusak dengan Mempertimbangkan Kualitas, Jakarta: Institut Pemerintahan Dalam Negeri, 2009.

[7] H.-K. Chen, C.-F. Hsueh dan M.-S Chang, "Production scheduling and vehicle routing with time windows for perishable food products," Computer \& Operation Research, vol. 36, no. 7, pp. 2311-2319, 2009. 
[8] N. Moungla, L. Letocart dan A. Nagih, "An improving dynamic programming algorithm to solve shortest path problem with time window," Transportation Research, pp. 931-938, 2010.

[9] F. P, G. F, L. D dan M. R, "Solving the shortest path tour problem," European Journal of Operational Research, vol. 230, no. 3, pp. 464474, 2013.

[10] W. Hu, A. Toriello dan M. Dessouky, "Integrated inventory routing and freight consolidation for perishable goods," European Journal of Operational Research, vol. 271, no. 2, pp. 548-560, 2018.

\section{BIOGRAFI PENULIS}

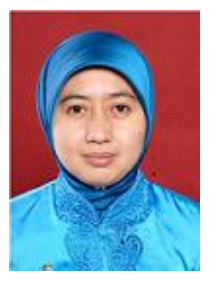

Winanda Kartika, lahir di Bukittinggi, 13 Februari 1985. Penulis tercatat sebagai dosen Manajemen Logistik di Politeknik APP Jakarta (2015sekarang). Menyelesaikan pendidikan Program Pascasarjana Teknik dan Manajemen Industri pada bidang Manajemen Rantai Pasok pada tahun 2013. Penulis pernah melakukan penelitian pada bidang Transportasi, Manajemen Inventori, dan Pergudangan. 